SUSTAINABLE FORESTRY

COLLECTION 75-76, 2017
ODRŽIVO ŠUMARSTVO

ZBORNIK RADOVA 75-76, 2017

UDK502.174+502.51:504.5=111

UDK 574.63:628.3=111

Original scientific paper

\title{
CONSTRUCTION OF FLOATING TREATMENT WETLANDS FOR REMEDIATION OF POLLUTED WATERS
}

\author{
Nevena ČULE ${ }^{1}$, Aleksandar LUČIĆ ${ }^{1}$, Dragana DRAŽIĆ ${ }^{1}$, \\ Vladan POPOVIĆ ${ }^{1}$, Milorad VESELINOVIĆ ${ }^{1}$, \\ Ljiljana BRAŠANAC-BOSANAC ${ }^{1}$, Suzana MITROVIĆ ${ }^{1}$
}

\begin{abstract}
Water regulation, integral water management and water conservation are one of the main tasks, set by an ecologically conscious society. A series of complex treatments are set in order to achieve the main goal in wastewater treatment, i.e. eliminating or reducing pollutants to a level that will not cause adverse effects to humans and the environment. The paper presents the construction of an efficient, environmentally friendly and economically justified biological system for the treatment of polluted urban waters. Research has shown that the proposed system with floating islands and algae was effective in removing various categories of pollutants from polluted river (organic and inorganic matter, heavy metals and pathogenic microorganisms), which indicated that the selected type of construction was appropriate. It was concluded that minor modifications in terms of cell coverage by floating islands could provide even greater removal of certain pollutants such as nitrogen, phosphorus and heavy metals.
\end{abstract}

Key words: floating treatment wetlands, polluted waters, construction, Canna indica, decorative macrophytes

\section{KONSTRUKCIJA SISTEMA SA PLUTAJUĆIM OSTRVIMA ZA REMEDIJACIJU ZAGAĐENIH VODA}

\footnotetext{
${ }^{1}$ Dr Nevena Čule, Dr Aleksandar Lučić, Dr Dragana Dražić, Dr Vladan Popović, Dr Milorad Veselinović, Dr Ljiljana Brašanac-Bosanac, Dr Suzana Mitrović, Institute of forestry, Belgrade, Serbia

Corresponding author: Nevena Čule, Kneza Višeslava 3, 11030 Belgrade, Serbia, tel.: +381 11 3553355, e-mail: nevena.cule@yahoo.com
} 
Izvod: Uređenje, integralno upravljanje vodama i njihova zaštita su jedan od glavnih zadataka, koje sebi postavlja jedno ekološki svesno društvo. Kako bi se dostigao glavni cilj u prečišćavanju otpadnih voda odnosno eliminisanju ili redukovanju zagađujućih materija do nivoa koji neće izazvati negativne efekte kod čoveka i životne sredine, postavljen je niz kompleksnih tretmana. U radu je prikazana konstrukcija efikasnog, ekološki prihvatljivog i ekonomski isplativog biološkog sistema za tretman zagađenih urbanih voda. Istraživanja su pokazala da je predloženi sistem sa plutajućim ostrvima i algama bio efikasan u uklanjanju različitih kategorija polutanata iz zagađene reke (organske i neorganske materije, teški metali i patogeni mikroorganizmi), što je ukazalo da je odabrani tip konstrukcije bio odgovarajući. Zaključeno je da bi manje modifikacije u pogledu pokrivenosti bazena plutajućim ostrvima mogle da obezbede još veće uklanjanje pojedinih polutanata kao što su azot, fosfor i teški metali.

Ključne reči: sistem sa plutajućim ostrvima, zagađene vode, konstrukcija, Canna indica, dekorativne makrofite

\section{INTRODUCTION}

Rivers and lakes are profoundly significant in urban areas since they represent one of the few remaining natural elements of the city. Instead of enhancing the quality of the environment and improving the surrounding landscape, small watercourses are often used as wastewater and rainwater collectors of industries and settlements, and thus additionally endanger the waters they flow into (Čule, 2016). Various inorganic substances and pathogenic microorganisms can pollute rivers and their banks to such an extent that they can be used neither for recreation nor for simple enjoyments, such as taking a walk since the river and its surroundings often have a very unpleasant smell and unsightly look.

One of the most polluted and highly endangered urban watercourses is the Topčiderka River in the entire area of its catchment. This river is used as a wastewater and rainwater collector of industries and settlements. Therefore, according to its chemical, physiochemical and microbiological water parameters, it is mainly within the limits of category $\mathrm{V}$ all the year round (Group of authors, 2013). The sources of anthropogenic pollution of the Topčiderka River are numerous and include: industrial effluence, industrial waste, exploitation of mineral resources, combustion of fossil fuels, traffic, exhaust gases, application of mineral and organic fertilizers and pesticides, stormwater runoff, unregulated landfills, improper disposal of the sewage sludge, the sewage system, septic tanks, etc. (Group of authors, 2016).

There are different types of biological systems that can help restore and maintain the physical, chemical and biological integrity of water. The floating treatment wetland (FTW) systems are modified aquatic ecosystems which can use the symbiotic relationship between their main components (plants, microorganisms, algae, substrates and water) to remove various pollutants from the polluted and wastewater in a completely natural way and with high efficiency (Hammer, 1989; Shutes, 2001; Goulet et al., 2001). This is an innovative technology that is gaining more and more significance since it has some advantages 
over other alternative water treatment technologies (Dodkins and Mendzil, 2014). Floating treatment wetlands are very simple to construct. They consist of a floating support, which carries the substrate for the growth of terrestrial and aquatic plants. Having been planted, the plants develop a significant mass of the root system which is in the direct contact with the water. This system allows better absorption of pollutants from the water, better removal of solids from the system, creation of more suitable sites for binding useful microorganisms, etc (Van de Moortel et al., 2010). The biomass obtained at the end of the treatment process can be easily removed and used for various purposes (Raskin et al., 1997; Flathman and Lanza, 1998; Zhu et al., 1999; Zhao et al., 2012). Apart from water purification as the most direct benefit, floating treatment wetland systems further increase the biodiversity of degraded areas, raise the value of the land and real estate in the areas surrounding the revitalized rivers or lakes, enhance the aesthetic value of the environment and potential of the area for tourism, etc (Ghermandi et al., 2010).

In order to start the revitalization of the Topčiderka River, pilot-scale facility for polluted water treatment was installed on its bank. The main goal of the research was to provide an environmentally-friendly, efficient and cost-effective solution for the treatment and revitalization of polluted urban river, and to use the obtained results and conclusions to create a model of floating treatment wetlands that could be used for water purification of other rivers, canals, wetlands and lakes.

\section{MATERIAL AND METHOD}

The construction of the collecting tank and cells as well as their layout were carried out on the basis of a previously completed project, which followed the basic guidelines for the construction of FTW systems set by other researchers (Yang et al., 2008; Stewart et al., 2008; Van de Moortel et al., 2010; White and Cousins, 2013; Dodkins and Mendzil, 2014). Certain modifications were made in order to adapt the biological system to this case and this research.

The vegetation of the floating islands included plant species, which according to the relevant scientific papers, studies and projects and on the basis of previous research conducted by the authors, meet the basic requirements of a good phytoremediation plant (Dushenkov et al., 1995; Salt et al., 1995; Kumar et al., 1995; Cunningham i Ow, 1996; Blaylock et al., 1997; Flathman and Lanza, 1998; Zhu et al., 1999; Blaylock and Huang, 2000; Dushenkov and Kapulnik, 2000; Čule et al., 2011; Čule et al, 2016). The selected species of the biological system included the following: Phragmites australis (Cav.) Trin. ex Steud., Canna indica L., Iris pseudacorus L., Iris sibirica 'Perry's Blue', Alisma plantago - aquatica L., Lythrum salicaria L. and Menyanthes trifoliata L. The system excluded invasive species and species that could in any way endanger the vegetation either in the surroundings of the river or in the nursery. The plant material was obtained from different nurseries, and before being transplanted into the FTW system it had been grown in an improvised pond (reed) or in containers filled with peat moss (other plants). The control plants were grown in plastic containers filled with water without the addition of nutrients until the end of the experiment.

The algae were brought into the biological system from the riverbed. It was determined that a monoculture of a macroscopic alga from the genus of 
Cladophora sp. developed in the cell by the end of the experiment. Further determination of the alga species was difficult because there were no other structures on the talus, but it was presumed to be the C. glomerata (Linnaeus) Kützing. since this alga is widespread and quite numerous in the rivers similar to the Topčiderka River.

After the FTW system had been completely established and put into work at the end of August, several different experiments were carried out (Čule, 2016) till the end of the vegetation period (late October). The aim of the experiments was to determine the efficiency of the installed system to remove various categories of pollutants from the polluted river.

Sampling and analysis of polluted and treated water, plants, algae and substrates in the system and in the control, the assessment of the obtained biomass at the end of the vegetation period, as well as the processing of the obtained results was performed according to the predefined methodology (Čule, 2016).

\section{RESULTS}

The system with floating wetlands for the treatment of polluted water of the Topčiderka River was constructed as a temporary structure. It was located on the bank of the Topčiderka River in the nursery of the Public Enterprise for Forest Management `Srbijašume`, Belgrade, FE `Belgrade`. It was designed as a modified rhizofiltration system and consisted of a pump for drawing water from the river, a closed collection tank, four open rectangular cells in which the floating islands were placed, floating islands with the substrate and the plants, an open rectangular cell with algae and a recirculation pump.

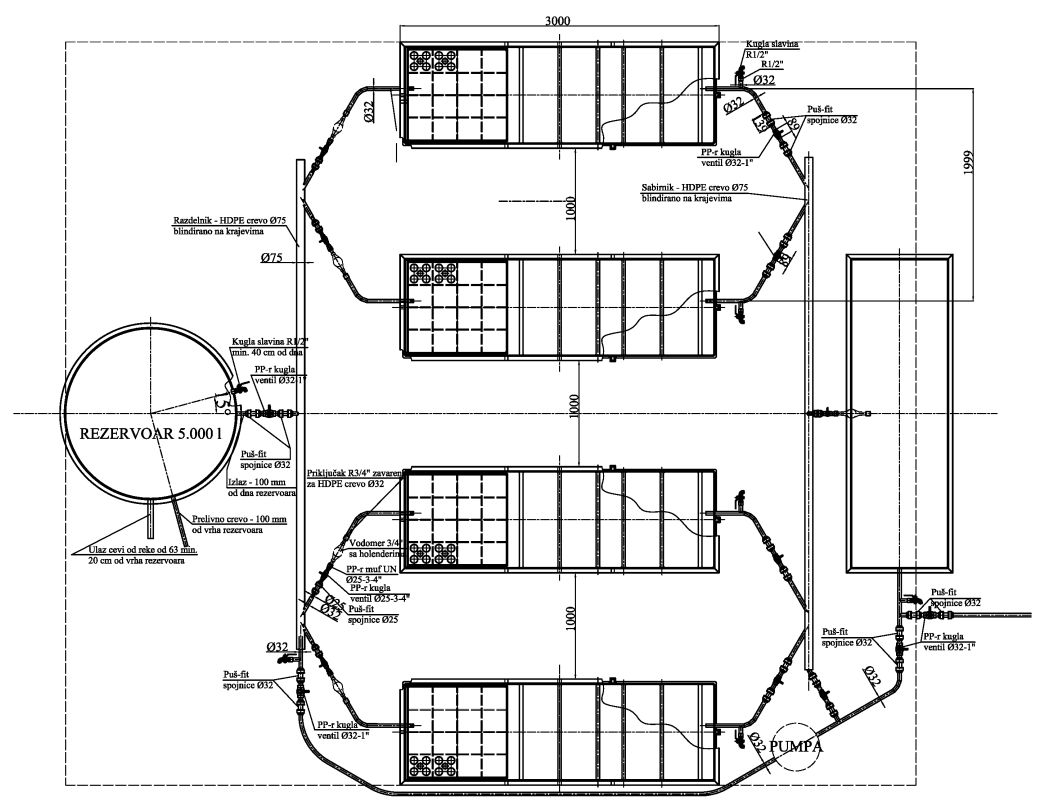

Figure 1. The scheme of the floating treatment wetland system 
An Oleo-Mac SA 45 TL self-priming water pump was used to draw the polluted water from the river into the biological system and a WP 300 euro 2 selfpriming water pump of the same manufacturer was used for the possible recirculation of the water in FTW system.

The collection tank and the cells were made of plastic mass. The tank was a typical vertical reservoir with acceptance volume of $5 \mathrm{~m}^{3}$ and internal dimensions of $\varnothing 1.6 \mathrm{~m} \times 2.5 \mathrm{~m}$. Four open rectangular cells had acceptance volume of $3 \mathrm{~m}^{3}$ each. The internal dimensions of the FTW cells were $3 \mathrm{~m} \times 1 \mathrm{~m} \times 1 \mathrm{~m}$. The cells had external metal and internal plastic reinforcements. Each cell had three floating islands measuring $1 \times 1 \mathrm{~m}$. The supports of the floating islands were constructed in the form of floating mesh platforms with handles. They were made of light thermoplastic materials. The supports were filled with stone wool which was used as a substrate for the plant growth. The floating islands of the first cell were planted with $P$. australis and the islands of the second cell with $C$. indica. Indian shoot and reed were planted together in the third cell, and I. pseudacorus, I. sibirica 'Perry's Blue', A. plantago - aquatica, L. salicaria and M. trifoliata in the fourth one. The first three cells had 25 plants on each island, while there were 30 decorative macrophytes on each island of the fourth cell. This method of planting provided the same microclimatic conditions for each species in the biological system and thus their easy comparison in the analysis of the obtained results. The fifth cell had acceptance volume of $1.5 \mathrm{~m}^{3}$, internal dimensions of $3 \mathrm{~m} \times 1 \mathrm{~m} \times 0.5 \mathrm{~m}$ and external metal reinforcements. It contained algae.

The collection tank and the cells were placed on the leveled land so that the entire bottom surface area of each cell lied flat on the substrate. Each inlet branch had a water meter and a DN 25 seal with corresponding fittings installed. The outflow branches contained seals and sampling taps, all of which were PE OD 32 with fittings.

The inlet and outlet branches of the collection tank and the cells were constructed at appropriate heights to provide the gravity flow of water. The outlet of the collection tank was at $10.5 \mathrm{~cm}$ above the bottom. Having deleveled the terrain by $20 \mathrm{~cm}$, it was possible to set up the inlets of the four cells at $30.5 \mathrm{~cm}$ and the outlets at $11 \mathrm{~cm}$ above the bottom of the cells. The water was fed into the fifth cell with algae from above since the inlet was placed on the upper edge of the cell or $50 \mathrm{~cm}$ above the ground level. The outlet of the last cell was set at $10 \mathrm{~cm}$ above the bottom of the cell. The biological system and its components were installed and checked for proper operation in one day.

Start-up period and monitoring of the proper work of the biological system was completed by the end of August (a month and a half after the system was installed). During this period, water was changed in the cells twice a week and the river water was pumped in. The biological system was monitored several times a week both in this period of its start-up and later when it was put into operation. In this way, we monitored the health status and the growth of plants, the occurrence of undesirable vegetation, the level of water in the system and the uniformity of its flow. 


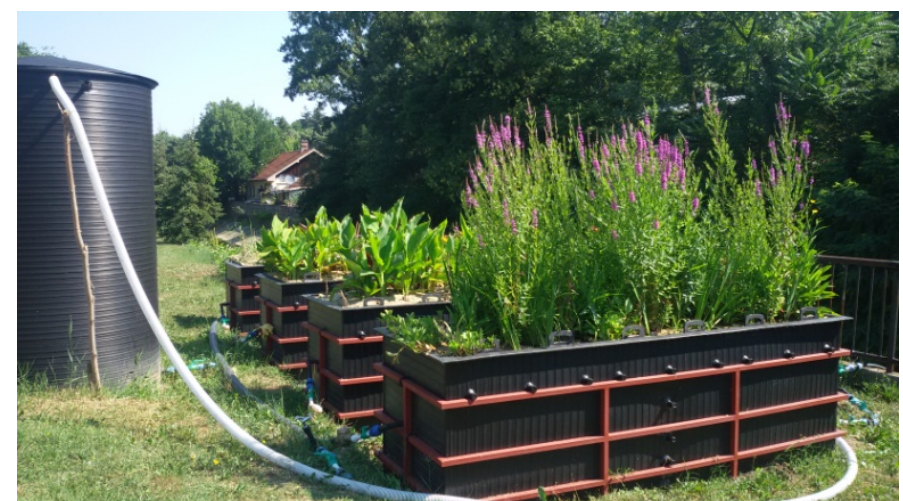

Figure 2. The cells with plants a month and a half after the planting

\section{DISCUSSION}

The analysis of the obtained results on the content of various pollutants in the polluted and purified water (total phosphorus, total nitrogen, ammonium nitrate, nitrites, nitrates, organic matter characterized by biological and chemical oxygen demand and total organic carbon, heavy metals and other elements of interest, fecal coliform bacteria, total coliform bacteria and fecal streptococci) as well as on the content of heavy metals and other investigated elements in plants, algae and substrates showed that the constructed FTW system was highly efficient in the treatment of polluted water (Čule, 2016). The high efficiency of the biological system in the removal of various pollutants from the polluted water is also evidenced by the fact that according to the content of the pollutants that are taken as parameters for the assessment of the ecological status of waters $(* * *$, $2011)$, or according to the limit values of pollutants in surface waters $(* * *, 2012)$, the influent water was classified into categories V to III, while it belonged to category I or II when leaving the last cell (Čule, 2016). The results also show that during the growing period all the investigated species in the biological system grew rapidly and thus produced significant quantities of belowground and aboveground biomass. They were resistant to different environmental conditions, pests and diseases and had high regeneration capacity. Furthermore, the establishment of plants, their transplanting into the biological system and maintenance of the floating island vegetation was simple (Čule, 2016). All these findings prove that this was the right model to be selected for the design of the FTW.

However, when the performance of individual cells with plants and algae was analyzed, it was found that the constructed system had certain drawbacks and small modifications could increase the efficiency of each individual cell. It primarily referred to determining the optimal coverage of a cell by vegetation i.e. by floating island. The available literature offers various data on this parameter, and it primarily depends on the type of pollutants to be removed from polluted or wastewater. The FTW cell coverage may range from a maximum of $100 \%$ to as little as 8-9\% (Yang et al., 2008; Stewart et al., 2008; Van de Moortel et al., 2010; White and Cousins, 2013; Borne et al., 2013; Chang et al., 2013). In the construction of such systems, it should be kept in mind that the coverage greater 
than $50 \%$ can create an anaerobic environment, which may result in poor removal of certain pollutants. On the other hand, the coverage of only $9-18 \%$ may be insufficient for the water treatment to be successful (Dodkins and Mendzil, 2014).

The 100\% FTW cell coverage in this research created an anaerobic environment in the cells with plants. This led to the low removal of phosphorus in the cells with plants, while it was extremely high (87\%) after the water had passed through the last cell i.e. the cell with algae which had a large free surface of water (Čule, 2016). Masters (2012) states that the process of $P$ removal is much more effective in the systems with floating islands compared to other constructed aquatic ecosystems, because the large free root surface allows rapid filtration of solid particles from the water which are then precipitated with P. It is assumed that the anaerobic conditions in the cells with plants have led to the release of sequestered and precipitated P back into the water. The extremely low content of dissolved oxygen in water brought about sulfate reduction which resulted in the formation of sulfides, which are in water primarily bound to $\mathrm{Fe}$ and $\mathrm{Al}$ and thus prevent the binding of $\mathrm{P}$ to $\mathrm{Fe}$ and $\mathrm{Al}$ oxides (Kadlec and Wallace, 2009). Another cause of the additional resuspension of $\mathrm{P}$ in the biological system could have been the turbulence of water caused by the inflow of new quantities of water into the cells or raise of gases from the bottom of the cells. These gases occur during the process of photosynthesis in water (oxygen) or decomposition of organic matter by microorganisms (methane and carbon dioxide) (US EPA, 2000). Based on this, it can be further assumed that the efficiency of the cells with plants in sulfur removal was low because of the initiation of these processes in the anaerobic environment. Although the nitrification process requires the aerobic environment, on the basis of the results on the performance of the cells with plants in the removal of ammonium nitrogen and the fact that the cells had anaerobic conditions, it can be concluded that the amount of oxygen found in the plant rhizosphere was quite sufficient for the process to be carried out smoothly. Another proof of this assertion is that the smallest reduction of $\mathrm{NH}_{4}-\mathrm{N}(45 \%)$ was achieved in the second cell - the cell with C. indica - where the belowground biomass was small due to the deterioration of a part of the plants (Čule, 2016). Other cells had high removal efficiency which amounted to $78-83 \%$ (Čule, 2016). However, the anaerobic conditions in the cells caused poor nitrite removal. In such conditions, the nitrification process could not be fully performed, i.e. it was impossible to convert all the available $\mathrm{NH}_{4}-\mathrm{N}$ into nitrates. Bernet et al. (2001) state that low concentrations of dissolved oxygen in water can lead to the formation of toxic $\mathrm{NO}_{2}-\mathrm{N}$, as the intermediate stage in the conversion of $\mathrm{NH}_{4}-\mathrm{N}$ to $\mathrm{NO}_{3}-\mathrm{N}$. Anaerobic water conditions in the cells with plants have enabled the high efficiency of $\mathrm{NO}_{3}-\mathrm{N}$ removal (79\%) from the polluted water due to denitrification (Čule, 2016). Such conditions in the cells, together with the plants and microorganisms have led to an effective reduction of $\mathrm{BOD}_{5}$ (8491\%), COD (57-91\%), TOC (16-20 \%) and the number of pathogenic microorganisms (100\%) (Čule, 2016). 


\section{CONCLUSION}

Based on the presented results, it can be concluded that the proposed FTW system can provide efficient removal of phosphorus, nitrogen, organic matter, pathogenic microorganisms and other pollutants from polluted water of the river. Thanks to its construction, the biological system provided unhindered development of physical, chemical and biological processes that took place within its basic components and produced purified water whose ecological status could be characterized as excellent (category I) or good (category II). The research also indicates that it is necessary to make certain modifications of the biological system in order to increase its efficiency in phosphorus and nitrite elimination. In the case of phosphorus, it is necessary to reduce the vegetation coverage in order to create conditions suitable for the undisturbed development of the main physical processes of phosphorus removal and to prevent its resuspension in water. In this way, there would be enough free space for the contact of the water with the air, which would allow the introduction of the required quantities of oxygen into the water. Since phosphorus is removed from the water mainly through the processes of filtration and sediment deposition, in order to avoid its return to water it is necessary to conduct periodical removal of the accumulated sediment from the bottom of the system. In order to eliminate nitrogen or increase the removal of nitrites in the FTW system, it is necessary to provide both aerobic and anaerobic conditions, which means that, as in the case of phosphorus, the percentage of vegetation coverage should be reconsidered. Finally, it can be concluded that in order to efficiently remove various pollutants using an FTW system, it is best to provide cells with alternating anaerobic and aerobic conditions. It is also recommended to provide a series of cells with algae at the end of the system. Their function would be to provide additional water polishing.

\section{LITERATURE}

*** (2011): Rulebook on parameters of ecological and chemical status of surface waters and parameters of chemical and quantitative status of groundwater (in Serbian). Official Gazette of RS, no. 74/2011.

*** (2012): Regulation on Limit Values of Pollutants in Surface and Groundwater and Sediment and Deadlines for their Completion (in Serbian). Official Gazette of RS, no. $50 / 2012$

Bernet, N., Dangcong, P., Delgenes, J.P., Moletta, R. (2001): Nitrification at low oxygen concentration in biofilm reactor. Journal of environmental engineering, 127(3), 266-271.

Blaylock, M.J. and Huang, J.W. (2000): Phytoextraction of metals. In: I. Raskin and B.D. Ensley eds. Phytoremediation of toxic metals: using plants to clean-up the environment. New York, John Wiley \& Sons, Inc.,53-70.

Blaylock, M.J., Salt, D.E., Dushenkov, S., Zakharova, O., Gussman, C., Kapulnik, Y., Ensley, B.D. and Raskin. I. (1997): Enhanced accumulation of Pb in Indian mustard by soil-applied chelating agents. Environmental Science and Technology, 31 (3), 860- 865. 
Borne, K.E., Fassman, E.A., Tanner, C.C. (2013): Floating treatment wetland retrofit to improve stormwater pond performance for suspended solids, copper and zinc. Ecological Engineering 54, 173-182.

Chang, N.B., Xuan, Z., Marimon, Z., Islam, K., Wanielista, M.P. (2013): Exploring hydrobiogeochemical processes of floating treatment wetlands in a subtropical stormwater wet detention pond. Ecological Engineering 54, 66-76.

Cule, N., Jovanovic, Lj., Drazic, D., Veselinovic, M., Mitrovic, S., Nesic, M. (2011): Indian shoot (Canna indica L.) in phytoremediation of water contaminated with heavy metals. Sustainable Forestry 63-64, 51-64. UDK 502.51:504.5]+502.174:582.548.25 Canna indica=111, ISSN 1821-1046, COBISS SR-ID 157148172.

Cunningham, S.D. and Ow, D.W. (1996): Promises and prospects of phytoremediation. Plant Physiology, 110(3), 715-719.

Čule, N. (2016): Phytoremediation of polluted water by plant Canna indica L. and selected decorative macrophytes (in Serbian). Fitoremedijacija zagađenih voda biljkom Canna indica L. i odabranim dekorativnim makrofitama. Doktorska disertacija. Univerzitet u Beogradu, 258. http://harvester.rcub.bg.ac.rs/handle/123456789/5192

Dodkins, I., Mendzil, A.F. (2014): Enterprise Assist: Floating Treatment Wetlands: Treatment efficiency and potential benefits of activated carbon. Sustainable Expansion of the Applied Coastal And Marine Sectors (SEACAMS), Swansea University, Swansea, Wales. 44.

Dushenkov, S. and Kapulnik, Y. (2000): Phytofilitration of metals. In: I., Raskin. and B.D., Ensley (eds.): Phytoremediation of toxic metals - using plants to clean-up the environment. New York, John Wiley \& Sons, Inc., 89-106.

Dushenkov, S., Kumar, P.B.A.N., Motto, H. and Raskin, I. (1995): Rhizofiltration: the Use of Plants to Remove Heavy Metals From Aqueous Streams. Environ Sci Technol., 29(5), 1239-1245.

Flathman, P.E. and Lanza, G.R. (1998): Phytoremediation: Current Views On An Emerging Green Technology. Journal Of Soil Contamination, Vol. 7, No. 4, 415-432.

Ghermandi, A., van den Bergh, J.C.J.M., Brander, L.M., de Groot, H.L.F., Nunes, P.A.L.D. (2010): Values of natural and human-made wetlands: A meta-analysis. Water Resourources Research, 46, W125116, 1-12.

Goulet, R. R., Pick, F. R., Droste R.L. (2001): Test of the first-order removal model for metal retention in a young constructed wetland. Ecological Engineering, 17, 357-371.

Group of authors (2013): Quality of the environment of the city of Belgrade in 2012. Secretariat for Environmental Protection, Belgrade; The Institute of Public Health of Belgrade; Regional Environmental Center for Central and Eastern Europe (REC). ISBN 978-86-7550-072-8. 
Group of authors (2016): Revitalization of the Topčiderka River by biological systems for purification of polluted waters (in Serbian). Project of the Institute for Forestry, Belgrade, financed by the City of Belgrade, Belgrade City Administration, Secretariat for Environmental Protection, 258.

Hammer, D. A. (ed.) (1989): Constructed Wetlands for Wastewater Treatment: Municipal, Industrial and Agricultural, Lewis Publishers, Chelsea, MI, 831.

Kadlec, R.H., Wallace, S.D. (2009): Treatment Wetlands (2nd Edition). CRC Press, Taylor \& Francis, Boca Raton, Florida, 1016.

Kumar, PBAN., Dushenkov, V., Motto, H., Raskin, I. (1995): Phytoextraction: the use of plants to remove heavy metals from soils. Environmental science \& technology, 29(5), 1232-1238.

Masters, B. (2012): The ability of vegetated floating Treatment wetlands to improve water quality in natural and constructed wetlands: a review. Water Practice and Technology, 7(1), doi:10.2166/wpt.2012.022.

Raskin I., Smith R.D. and Salt D.E. (1997): Phytoremediation of metals: using plants to remove pollutants from the environment. Current Opinion in Biotechnology, 8(2), 221-226.

Salt, D.E., Blaylock, M., Kumar, N.P.B.A., Dushenkov, V., Ensley, D., Chet, I. and Raskin, I. (1995): Phytoremediation: a novel strategy for the removal of toxic metals from the environment using plants. Biotechnology, 13, 468-474.

Shutes, R.B.E. (2001): Artificial wetlands and water quality improvement. Environmental International, 26, 441-447.

Stewart, FM., Mulholland, T., Cunningham, AB., Kania, BG., Osterlund, MT. (2008): Floating treatment wetlands as an alternative to constructed wetlands for treatment of excess nutrients from agricultural and municipal wastes - results of laboratory-scale tests. Land Contamination \& Reclamation, 16 (1), 25-33.

U.S. EPA (2000): Manual - Constructed Wetlands Treatment of Municipal Wastewater. U.S. Environmental Protection Agency. Report no. EPA/625/R-99/010. Office of Research and Development, Cincinnati, OH, 165.

Van de Moortel, A.M.K., Meers, E., Pauw, N., Tack, F.M.G. (2010): Effects of Vegetation, Season and Temperature on the Removal of Pollutants in Experimental Floating Treatment Wetlands. Water, Air, \& Soil Pollution 212, 281-297.

White, S.A., Cousins, M.M. (2013): Floating treatment wetland aided remediation of nitrogen and phosphorus from simulated stormwater runoff. Ecological Engineering, 61, 207-215.

Yang, Z., Zheng, S., Chen, J., Sun, M. (2008): Purification of nitrate-rich agricultural runoff by a hydroponic system. Bioresource technology 99: 8049-8053. 
Zhao, F., Xi, S., Yang, X., Yang, W., Li, J., Gu, B., He, Z. (2012): Purifying eutrophic river waters with integrated floating treatment wetland systems. Ecological Engineering, 40, 5360 .

Zhu, Y.L., Zayed, A.M., Quian, J.H., De Souza, M., Terry, N. (1999): Phytoaccumulation of trace elements by wetland plants: II. Water hyacinth. Journal of Environmental Quality, 28, 339-344.

\title{
CONSTRUCTION OF FLOATING TREATMENT WETLANDS FOR REMEDIATION OF POLLUTED WATERS
}

\author{
Nevena ČULE, Aleksandar LUČIĆ, Dragana DRAŽIĆ, Vladan POPOVIĆ, \\ Milorad VESELINOVIĆ, Ljiljana BRAŠANAC-BOSANAC, Suzana MITROVIĆ
}

\section{Summary}

One of the examples of polluted and highly endangered urban river is the Topčiderka River with the entire area of its catchment. This river is used as a wastewater and rainwater collector of industries and settlements. Therefore according to the chemical, physiochemical and microbiological water parameters, it is mainly within the limits of category $\mathrm{V}$ all the year round. In order to start the revitalization of the Topčiderka River, pilot-scale facility for the treatment of polluted water was installed on its bank. The FTW system was designed as a modified rhizofiltration system and included a pump for drawing water from the river, a closed collection tank, four open rectangular cells in which the floating islands were placed, floating islands with the substrate and the plants, an open rectangular cell with algae and a recirculation pump. The vegetation of the biological system included the following species: Phragmites australis (Cav.) Trin. ex Steud., Canna indica L., Iris pseudacorus L., Iris sibirica 'Perry's Blue', Alisma plantago - aquatica L., Lythrum salicaria L. and Menyanthes trifoliata L. There was one cell with algae. The analysis of the obtained results on the content of various pollutants in the polluted and purified water as well as on the content of heavy metals and other investigated elements in plants, algae and substrates showed that the FTW system was highly efficient in the treatment of polluted water. The high efficiency of the biological system in the removal of various pollutants is also evidenced by the fact that according to the content of the pollutants, the influent water was classified into categories V to III, while it belonged to category I or II when leaving the last pond. It can be concluded that it is necessary to make certain modifications of the system in order to increase its efficiency in the removal of phosphorus and nitrite as well as other pollutants, which means that it is necessary to reduce vegetation coverage of some cells. Finally, it can be concluded that in order to efficiently remove various pollutants using an FTW system, it is best to provide cells with alternating anaerobic and aerobic conditions. It is also recommended to provide a series of cells with algae at the end of the system. Their function would be to provide additional water polishing. 


\title{
KONSTRUKCIJA SISTEMA SA PLUTAJUĆIM OSTRVIMA ZA REMEDIJACIJU ZAGAĐENIH VODA
}

\author{
Nevena ČULE, Aleksandar LUČIĆ, Dragana DRAŽIĆ, Vladan POPOVIĆ, \\ Milorad VESELINOVIĆ, Ljiljana BRAŠANAC-BOSANAC, Suzana MITROVIĆ
}

\section{Rezime}

Jedan od primera zagađenih i visoko ugroženih urbanih vodotokova je Topčiderska reka i to celom dužinom svoga sliva. Ova reka se koristi kao kolektor otpadnih i kišnih voda industrije i naselja tako da se tokom cele godine uglavnom nalazi u granicama V klase prema hemijskim, fizičko-hemijskim i mikrobiološkim parametrima voda. Kako bi se započeli radovi na revitalizaciji Topčiderse reke na njenoj obali je postavljeno pilot postrojenje za prečišćavanje zagađenih voda. Sistem sa plutajućim ostrvima je konstruisan kao modifikovan rizofiltracioni sistem i sastojao se od pumpe za zahvatanje vode iz reke, sabirnog zatvorenog rezervoara, četiri otvorena pravougaona bazena u koje se smeštaju plutajuća ostrva, plutajućih ostrva sa supstratom i biljkama, jednog otvorenog pravougaonog bazena sa algama i pumpe za recirkulaciju. Za formiranje vegetacije plutajućih ostrva odabrane su vrste: Phragmites australis (Cav.) Trin. ex Steud., Canna indica L., Iris pseudacorus L., Iris sibirica 'Perry's Blue', Alisma plantago - aquatica L., Lythrum salicaria L. i Menyanthes trifoliata L. U jednom bazenu su se nalazile alge. Analiza dobijenih rezultata o sadržaju različitih polutanata u zagađenoj i prečišćenoj vodi kao i sadržaju teški metali i drugi ispitivanih elementa u biljkama, algama i supstratu je pokazala da je konstruisani sistem sa plutajućim ostrvima bio vrlo efikasan u prečišćavanju zagađene vode. $\mathrm{O}$ visokoj efikasnosti biološkog sistema u uklanjanju različitih polutanata govori i podatak da je ulivna voda na osnovu sadržaja ispitivanih polutanata svrstana u V do III klasu, a da je po izlazu iz poslednjeg bazena imala karakteristike vode koja pripada klasi I ili II. Zaključeno je da neophodno izvršiti određene modifikacije sistema kako bi se dodatno povećala njegova efikasnost u eliminisanju fosfora i nitrita, kako i drugih polutanata odnosno da je u jednom broju bazena potrebno smanjiti procenat pokrivenosti plutajućim ostrvima. Na kraju se može zaključiti da je za efikasno uklanjanje različitih polutanata pomoću sistema sa plutajućim ostrvima najbolje obezbediti smenu bazena sa anaerobnim i aerobnim uslovima. Preporuka je i da se na kraju sistema nađe i serija bazena sa algama, koje će omogućiti dodatno poliranje vode. 